\title{
Determinan Intellectual Capital terhadap Profitabilitas di Bank Syariah: Pengujian Mediasi Kinerja Keuangan dan Kinerja Non Keuangan
}

\section{Determinant of Intellectual Capital on Profitability in Islamic Banks: Testing Mediation of Financial Performance and Non-Financial Performance}

\author{
Siti Mardilia Farihah ${ }^{1)}$, Setiawan Setiawan ${ }^{2)}$ \\ ${ }^{1,2)}$ Program Studi Keuangan Syariah, Politeknik Negeri Bandung, Bandung \\ e-mail korespondensi: setiawan@polban.ac.id
}

\begin{tabular}{|l|}
\hline Info Artikel \\
\hline Riwayat Artikel : \\
Diterima: 10 Januari 2020 \\
Disetujui: 01 April 2020 \\
Dipublikasikan: Juli 2020 \\
\hline Nomor DOI \\
10.33059/jseb.v11i2.1996 \\
Cara Mensitasi : \\
Farihah, S.M. \& Setiawan, S. \\
2020. Determinan Intellectual \\
Capital terhadap Profitabilitas \\
di Bank Syariah: Pengujian \\
Mediasi Kinerja Keuangan dan \\
Kinerja Non Keuangan. \\
Jurnal Samudra Ekonomi \\
dan Bisnis. 11(2): 151-165.
\end{tabular}

Tujuan penelitian ini adalah untuk menganalisis pengaruh intellectual capital terhadap kinerja keuangan dan kinerja non keuangan dari perbankan syariah, serta dampaknya terhadap profitabilitas bank tersebut. Populasi adalah 13 Bank Umum Syariah di Indonesia. Dengan metode purposive sampling, diperoleh sampel penelitian sebanyak lima Bank Umum Syariah. Metode analisis data dalam penelitian ini menggunakan SEM PLS. Hasil pertama menunjukkan bahwa intellectual capital berpengaruh negatif secara signifikan terhadap kinerja keuangan, berpengaruh positif secara signifikan terhadap kinerja non keuangan, serta berpengaruh positif namun tidak signifikan terhadap profitabilitas. Hasil berikutnya menyatakan kinerja keuangan maupun kinerja non keuangan berpengaruh negatif secara signifikan terhadap profitabilitas. Hasil penelitian ketiga menyatakan bahwa intellectual capital berpengaruh positif secara signifikan terhadap profitabilitas melalui kinerja keuangan, tetapi berpengaruh negatif secara signifikan terhadap profitabilitas melalui kinerja non keuanga.

Kata Kunci: Intellectual Capital, Kinerja Keuangan, Kinerja Non Keuangan, Maqashid Syariah Indeks, Profitabilitas.

\begin{tabular}{|c|c|}
\hline Article Info & Abstract \\
\hline $\begin{array}{l}\text { Article History: } \\
\text { Received: } 10 \text { January } 2020 \\
\text { Accepted: } 01 \text { April } 2020 \\
\text { Published: July } 2020\end{array}$ & $\begin{array}{l}\text { The purpose of this study is to analyze the effect of intellectual capital on } \\
\text { financial performance and non-financial performance of Islamic banking, and } \\
\text { its impact on the profitability of the bank. The population is } 13 \text { Sharia } \\
\text { Commercial Banks in Indonesia. With the purposive sampling method, a sample }\end{array}$ \\
\hline $\begin{array}{l}\text { DOI Number: } \\
\text { 10.33059/jseb.v11i2.1996 } \\
\text { How to cite : } \\
\text { Farihah, S.M. \& Setiawan, S. } \\
\text { 2020. Determinan Intellectual } \\
\text { Capital terhadap Profitabilitas } \\
\text { di Bank Syariah: Pengujian } \\
\text { Mediasi Kinerja Keuangan } \\
\text { dan Kinerja Non Keuangan. } \\
\text { Jurnal Samudra Ekonomi } \\
\text { dan Bisnis. 11(2): 151-165. }\end{array}$ & $\begin{array}{l}\text { of five Islamic commercial banks was obtained. Data analysis method in this } \\
\text { study uses SEM PLS. The first result shows that intellectual capital has a } \\
\text { significant negative effect on financial performance, a significant positive effect } \\
\text { on non-financial performance, and a positive but unsignificant effect on } \\
\text { profitability. The next results stated that financial performance and non- } \\
\text { financial performance had a significant negative effect on profitability. The } \\
\text { third research result states that intellectual capital has a significant positive } \\
\text { effect on profitability through financial performance, but a significant negative } \\
\text { effect on profitability through non-financial performance. } \\
\text { Keywords: Intellectual Capital, Financial Performance, Non-Financial } \\
\text { Performance, Maqashid Syariah Index, Profitability. }\end{array}$ \\
\hline
\end{tabular}




\section{PENDAHULUAN}

Pelayanan pada sektor syariah kepada masyarakat melalui lembaga bersangkutan dapat terpenuhi berkat hadirnya industri keuangan syariah (Prambodo \& Amanah, 2016). Hingga saat ini industri keuangan syariah terus berkembang dan mampu menghasilkan aset yang sangat besar terutama bank syariah (Setiawan, 2018). Namun, selayaknya perusahaan, tujuan utama dari perusahaan - termasuk di dalamnya bank syariah - adalah untuk mencapai laba yang optimal dari kegiatan usahanya. Kinerja dalam mencapai laba tersebut disebut dengan profitabilitas.

Profitabilitas adalah rasio yang dapat melihat sejauh mana perusahaan mampu menghasilkan laba (Hanafi \& Halim, 2009). Hijriyani \& Setiawan (2017) menyebutkan bahwa dalam beberapa tahun terakhir, kinerja bank syariah dalam menghasilkan laba terus membaik. Namun, bila dilihat dari sisi rasio profitabilitas menunjukkan sebaliknya. Hal ini lebih dipengaruhi oleh biaya operasional yang tinggi atau ada inefisiensi (Hijriyani \& Setiawan, 2017).

Tumbuhnya industri perbankan syariah ditopang berkat kemampuan dari perusahaan yang mampu mengelola semua sumber daya yang dimiliki. Sumber daya tersebut meliputi sumber daya berupa harta berwujud atau tangible assets serta sumber daya yang berupa harta tidak berwujud atau intangible asset (Wijaya \& Amanah, 2017; Prambodo \& Amanah, 2016). Pada saat ini, bank tidak hanya berorientasi pada pengembangan kemampuan di dalam menjual produknya. Namun saat ini bank terus meningkatkan kapasitas dalam menghasilkan maupun menyediakan produk maupun jasa untuk menjaga keberlangsungan perusahaan (Nasih, 2010). Sehingga aset pengetahuan atau knowledge assets menjadi salah satu hal yang penting dalam dunia usaha (Solikhah, 2010).
Semenjak era 90-an sudah mulai terlihat meningkatnya pengelolaan aset tak berwujud oleh perusahaan-perusahaan (Ulum, 2008; Harrison \& Sullivan, 2000). Dengan melihat fenomena, para peneliti menawarkan berbagai pendekatan untuk dapat mengukur penerapan aset tidak berwujud tersebut. Salah satu indikator yang dapat mengukur dan menilai aset tidak berwujud adalah menggunakan pendekatan berupa Intellectual Capital.

Intellectual Capital menjadi komponen penting bagi perusahaan dalam melihat nilai tambah untuk menjaga daya saing perusahan. Melalui manajemen yang baik dalam mengelola intellectual capital pada bank syariah, maka dapat dilihat pengaruhnya pada kinerja perusahaan (Meutuah \& Takidah, 2014). Penelitian ini mencoba untuk menguji pengaruh intellectual capital terhadap profitabilitas. Selain itu, penelitian ini juga menguji kinerja keuangan dan kinerja non keuangan non keuangan dalam memediasi hubungan tersebut.

Hasil penelitian ini diharapkan memberi kontribusi terhadap peran intellectual capital dalam upaya meningkatkan kinerja keuangan, kinerja non keuangan, serta profitabilitas di bank syariah khususnya dan perusahaan pada umumnya. Kontribusi itu dapat bermanfaat bagi pihak internal ataupun pihak eksternal dalam mengambil satu keputusan strategis (Almilia \& Kristijadi 2003).

\section{Intellectual Capital}

Pembahasan terkait intellectual capital mulai mengemuka semenjak kemunculan artikel dengan judul "Brain Power How Intellectual Captal Is Becoming America's Most Valuable Asset" yang ditulis oleh Stewart pada tahun 1991, dan berhasil mengantar intellectual capital memasuki agenda manajemen. Pada artikel tersebut, intellectual capital didefinisikan sebagai materi dari intelektual yang meliputi 
pengetahuan, informasi, properti intelektual dan pengalaman, yang dapat berguna dalam membangun kekayaan (Stewart, 1991).

Di samping yang telah dikemukakan Stewart, beberapa pakar dan lembaga pun telah memberikan berbagai definisi mengenai intellectual capital, seperti di antaranya Brooking (1996), Roos et. al (1997), Bontis (1998), dan Organisation for Economic Cooperation and Development (1999). Definisi Intellectual Capital yang paling banyak dirujuk sampai saat ini adalah seperti yang dikemukakan Organisation for Economic Cooperation and Development (OECD) bahwa intellectual capital merupakan nilai ekonomi dari dua kategori aset tak berwujud: (1) structural capital; dan (2) human capital (OECD, 1999).

\section{Kinerja Keuangan}

Melalui penilaian kinerja keuangan, maka pencapaian perusahaan dapat ikut terukur. Manajemen melakukan penilaian terhadap kinerja keuangan untuk memastikan perusahaan telah melaksanakan pengelolaan keuangannya dengan menggunakan aturanaturan pelaksanaan keuangan yang baik dan benar (Setyowati et al., 2019). Pengukuran kinerja merupakan bagian dari proses analisis kinerja keuangan.

Analisis kinerja keuangan adalah satu proses untuk mendalami kinerja keuangan dengan kritis, yang dapat ditinjau dari data keuangan, perhitungan, pengukuran, interpretasi serta memberikan alternatif solusi bagi masalah keuangan perusahaan pada periode tertentu (Harmono, 2014). Perusahaan dapat melakukan evaluasi menyeluruh perihal efektivitas serta efisiensi dalam pencapaian keuntungan ataupun untuk posisi kas tertentu terkait kinerja keuangan tersebut (Hanafi, 2003). Hal ini karena dengan pengelolaan keuangan yang baik dan efisien, dapat menghasilkan kinerja keuangan yang optimal
(Setyowati, et al., 2019). Selain itu, dengan pengukuran kinerja keuangan, perusahaan pun dapat melihat prospek perkembangan serta pertumbuhan perusahaan melalui pengelolaan sumber daya yang dimiliki.

\section{Kinerja Non Keuangan}

Kinerja non keuangan yang dimaksud dalam penelitian ini adalah maqashid syariah. Berdasarkan etimologi, maqashid syariah berasal dari 2 (dua) kata, yaitu maqashid serta syariah. Maqashid merupakan bentuk jamak dari maqshud yang memiliki arti tujuan atau kesengajaan. Sedangkan syariah artinya jalan menuju air, atau dapat diartikan sebagai jalan menuju pada sumber kehidupan. Menurut alGhazali (1985), maqashid syariah adalah penjagaan terhadap tujuan serta maksud syariah sebagai upaya mendasar dalam bertahan hidup, menahan faktor-faktor kerusakan dan mendorong tercapainya kesejahteraan.

Asy-Syatibi membagi maqashid syariah menjadi tiga tingkatan, yaitu maqashid addharuriyat, maqashid al-hajiyat, dan maqashid al-tahsiniyat. Terdapat dua cara agar lima unsur tersebut tetap terjaga. Pertama, dari segi ada (wujud), yaitu dengan cara menjaga dan memelihara hal-hal yang dapat melanggengkan keberadaan lima unsur tersebut. Kedua, dari segi tidak ada (min nahiyah al-adam) yaitu dengan cara mencegah hal-hal yang dapat menyebabkan ketiadaan lima unsur tersebut.

\section{Pengembangan Hipotesis}

Dalam sudut pandang Resource Based Theory (RBT) dikemukakan bahwa sumber daya yang dimiliki perusahaan sangat beragam, dan jasa produktif yang berawal dari sumber daya perusahaan menyajikan karakter unik bagi setiap perusahaan (Wernerfelt, 1984). Dengan pengelolaan sumber daya yang baik maka dapat dipastikan persaingan dapat 
dimenangkan oleh perusahaan. Sumber daya tersebut dapat berupa kompetensi serta keterampilan yang dimiliki oleh karyawan di perusahaan. Apabila potensi karyawan pada bank syariah dapat dikelola dengan baik maka produktivitas perusahaan akan ikut meningkat (Aminah, 2017).

Seperti menurut Stakeholder Theory, intellectual capital merupakan sumber daya yang memiliki peran dalam meningkatan keunggulan daya saing, sehingga mampu berkontribusi dalam peningkatan kinerja keuangan perusahaan (Chen et al., 2005). Selain dapat meningkatkan kinerja keuangan, intellectual capital-pun dianggap mampu memacu kinerja non keuangan. Dalam kaitannya dengan bank syariah, tentunya dapat dilihat dari sudut pandang maqashid syariah.

Walaupun hasil penelitian belum secara mutlak menemukan hubungannya, seperti penelitian yang dilakukan oleh Ramadhan et al. (2018) yang mengemukakan bahwa Islamic Banking-Value Added Intellectual Capital (iB-VACA) tidak memiliki pengaruh yang positif pada kinerja maqashid syariah, serta Islamic banking-Structural Capital Value Added (iB-STVA) tidak memiliki pengaruh terhadap kinerja maqashid syariah. Namun, Islamic banking-Value Added Human Capital (iB-VAHU) diketahui memiliki pengaruh positif terhadap kinerja maqashid syariah. Meskipun dari masing-masing komponen intellectual capital memiliki pengaruh yang berbeda terhadap kinerja maqashid syariah.

Berdasarkan dasar pemikiran yang telah diuraikan, hipotesis yang diajukan dalam penelitian ini adalah.

$\mathbf{H}_{\mathbf{1}}$ : Intellectual capital berpengaruh positif signifikan terhadap kinerja keuangan pada perbankan syariah.
$\mathbf{H}_{2}$ : Intellectual capital berpengaruh positif signifikan atas kinerja non keuangan pada perbankan syariah.

Jika produktivitas yang dihasilkan intellectual capital meningkat, maka kinerja keuangan syariah juga dapat meningkat. Beberapa hasil penelitian menunjukkan bahwa intellectual capital memiliki pengaruh yang positif terhadap kinerja keuangan diantaranya yang dilakukan oleh Chen et al. (2005); Lestari et al. (2016); serta Wijayani (2017). Semua penelitian itu menunjukkan bahwa meningkatnya intellectual capital di perusahaan akan diikuti oleh meningkatnya profitablitas. Melalui manajemen intellectual capital yang tepat, maka akan diperoleh nilai tambah sebagai keunggulan kompetitif bagi perusahaan. Berdasarkan uraian tersebut, hipotesis yang dapat diajukan adalah.

$\mathbf{H}_{3}$ : Intellectual capital berpengaruh positif signifikan terhadap profitabilitas pada perbankan syariah.

Peningkatan kinerja keuangan maupun kinerja non keuangan dapat berpengaruh positif terhadap pengembalian yang didapatkan stakeholder. Stakeholder atau pemangku kepentingan memiliki sebagian fungsi untuk pengendalian dalam pengelolaan sumber daya perusahaan. Sumber daya dimaksud termasuk juga sumber daya intelektual perusahaan. Atas dasar tersebut, hipotesis yang diajukan adalah:

$\mathbf{H}_{\mathbf{4}}$ : Kinerja keuangan berpengaruh positif signifikan terhadap profitabilitas pada perbankan syariah.

$\mathbf{H}_{5}$ : Kinerja non keuangan berpengaruh positif signifikan terhadap profitabilitas pada perbankan syariah. 
Pengelolaan dan pemanfaatan sumber daya strategis perusahaan dapat menciptakan nilai tambah serta keunggulan kompetitif yang akan bermuara pada peningkatan kinerja keuangan dan kinerja non keuangan pada perusahaan. Sumber daya penting tersebut bisa terdiri dari aset berwujud ataupun aset tak berwujud. Dalam hal aset tak berwujud, yaitu berupa aset intelektual perusahaan seperti inovasi, sistem informasi, budaya organisasi, dan sumber daya manusia. Ketika kinerja keuangan meningkat, return yang didapat stakeholder akan meningkat. Ketika return meningkat, maka perusahaan mampu memberikan keuntungan yang optimal kepada stakeholder dengan peningkatan profitabilitas.
Berdasarkan pemikiran tersebut, hipotesis yang dapat diajukan adalah:

$\mathbf{H}_{6}$ : Intellectual capital berpengaruh positif signifikan atas profitabilitas melalui kinerja keuangan pada perbankan syariah.

$\mathbf{H}_{7}$ : Intellectual capital berpengaruh positif signifikan atas profitabilitas melalui kinerja non keuangan pada perbankan syariah.

Paradigma yang dirancang untuk penelitian ini lebih jauh dapat dinyatakan seperti Gambar 1.

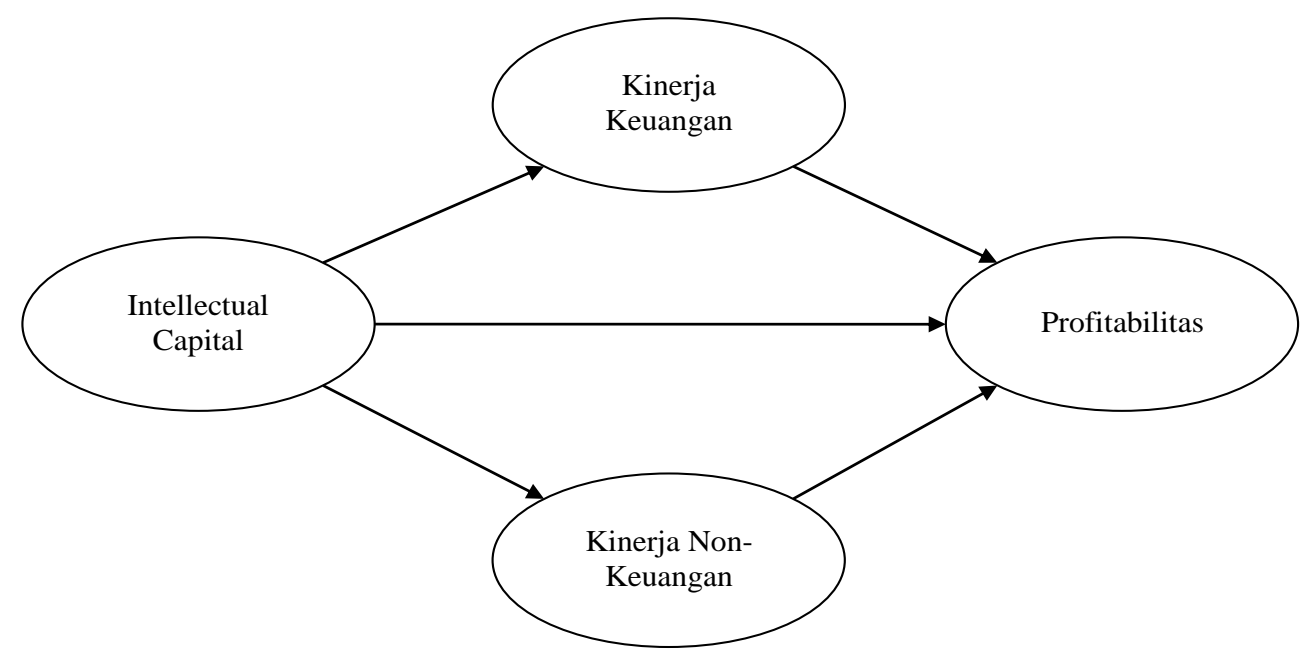

\section{Gambar 1. Paradigma Penelitian}

Sumber: Diolah penulis, 2019.

\section{METODE PENELITIAN}

Metode penelitian ini menggunakan pendekatan kuantitatif kausal. Pendekatan kuantiatif yang berfokus pada analisis data numerik yang kemudian diolah dengan menggunakan motode statistik tertentu. Sedangkan tujuan dari penelitian ini yaitu untuk membuktikan adanya hubungan kausalitas atau sebab-akibat, sebagaimana terdapat variabel yang mempengaruhi dan variabel yang dipengaruhi (Sugiyono, 2010). Dalam hal ini, diuji bagaimana intellectual capital dapat mempengaruhi kinerja keuangan dan kinerja non keuangan perbankan syariah serta dampaknya terhadap profitabilitas.

Populasi penelitian ini adalah seluruh Bank Umum Syariah yang ada di Indonesia, sedangkan sampel yang digunakan diambil menurut metode purposive sampling agar bisa menjadi representasi seluruh populasi. Syarat yang diajukan adalah Bank Umum Syariah menerbitkan laporan keuangan triwulan dari periode 2011 sampai 2017 secara berurutan. Selain itu, syarat lainnya adalah dari laporan 
keuangan tersebut, diharuskan terdapat komponen yang dijadikan dasar perhitungan variabel setiap variabel. Pemilihan periode dari 2011-2017 untuk mengakomodir periode yang cukup panjang tahun pengamatan agar dapat terlihat dinamika Bank Umum Syariah.

Setelah melalui seleksi berdasarkan kriteria yang ditentukan, terdapat lima bank syariah yang menjadi sampel dalam penelitian ini yakni PT. Bank BCA Syariah, PT. Bank BNI Syariah, PT. Bank BRI Syariah, PT. Bank Bukopin Syariah, dan PT. Bank Mega Syariah.

Penelitian ini menggunakan beberapa variabel. Variabel endogen dalam penelitan ini merupakan profitabilitas (ROA, ROE, NIM), variabel eksogen yaitu intellectual capital (iB-VAIC), dan variabel intervening adalah kinerja keuangan (NPF, CAR, dan BOPO), serta kinerja non keuangan maqashid syariah. Teknik penarikan sampel yang digunakan adalah teknik purposive sampling. Operasionalisasi dari masing-masing variabel yang dianalisis dalam penelitian ini dirangkum dalam Tabel 1.

Alat analisis yang digunakan dalam penelitian ini adalah Partial Least Square (PLS). Alat bantu analisis yang digunakan adalah SmartPLS versi 3.0. PLS merupakan salah satu metode untuk melaksanakan model Structural Equation Modelling (SEM). Keunggulan PLS yaitu dapat digunakan pada jumlah sampel kecil dan dapat diterapkan di semua skala data (Ghozali, 2008).

\section{HASIL ANALISIS}

Data yang diolah adalah data laporan keuangan Bank Umum Syariah triwulanan periode 2011-2017. Berdasarkan hasil uji statistik deskriptif, diperoleh sebanyak 140 data observasi. Pengukuran yang digunakan dalam penelitian ini adalah nilai maksimum, nilai minimum, mean, dan standar deviasi.
Hasil dari pengujian statistik deskriptif dapat dilihat pada Tabel 2.

Hasil analisis deskriptif pada Tabel 2 menunjukkan jumlah data yang diobservasi sebanyak 140. Dari sejumlah data tersebut, terdapat rata-rata, median, nilai paling kecil, nilai paling besar dan standar deviasi. Pada komponen intellectual capital terdapat data yang negatif, yaitu structural capital. Selain pada intellectual capital, capaian ROA dan ROE pada bank syariah ada juga yang mengalami nilai negatif. Artinya, bank syariah pernah tidak memperoleh return atas usahanya. Selebihnya, sebaran data terlihat baik dan bervariasi.

Selanjutnya dilakukan pengujian model pengukuran. Pengujian model pengukuran pada penelitian ini dilakukan melalui dua tahap, yaitu evaluasi terhadap convergent validity dan discriminant validity. Convergent validity bisa dianalisis dalam tiga tahapan, yaitu indikator validitas, reliabilitas konstruk, serta nilai Average Variance Extracted (AVE).

Berdasarkan Tabel 3, upaya percobaan pengujian convergent validity pertama menghasilkan beberapa indikator dengan outer loading dibawah 0,5. Item yang perlu dihapus diantaranya VACA dengan outer loading sebesar 0,42; NPF dengan outer loading sebesar 0,064; dan CAR dengan outer loading sebesar 0,213. Berdasarkan nilai hasil loading AVE pada Tabel 3 juga, belum dapat disimpulkan bahwa validitas konvergen telah terpenuhi. Artinya, keberadaan korelasi antar instrument yang berbeda, semuanya belum cukup valid. Pemenuhan validitas diskriminan dapat dilihat dari nilai cross loading konstruk. Jika korelasi indikator konstruk memiliki nilai lebih tinggi dibandingkan dengan korelasi indikator itu terhadap konstruk lain, maka dikatakan konstruk itu memiliki tingkatan validitas diskriminan yang tinggi (Ghozali, 2008). 
Tabel 1. Operasionalisasi Variabel

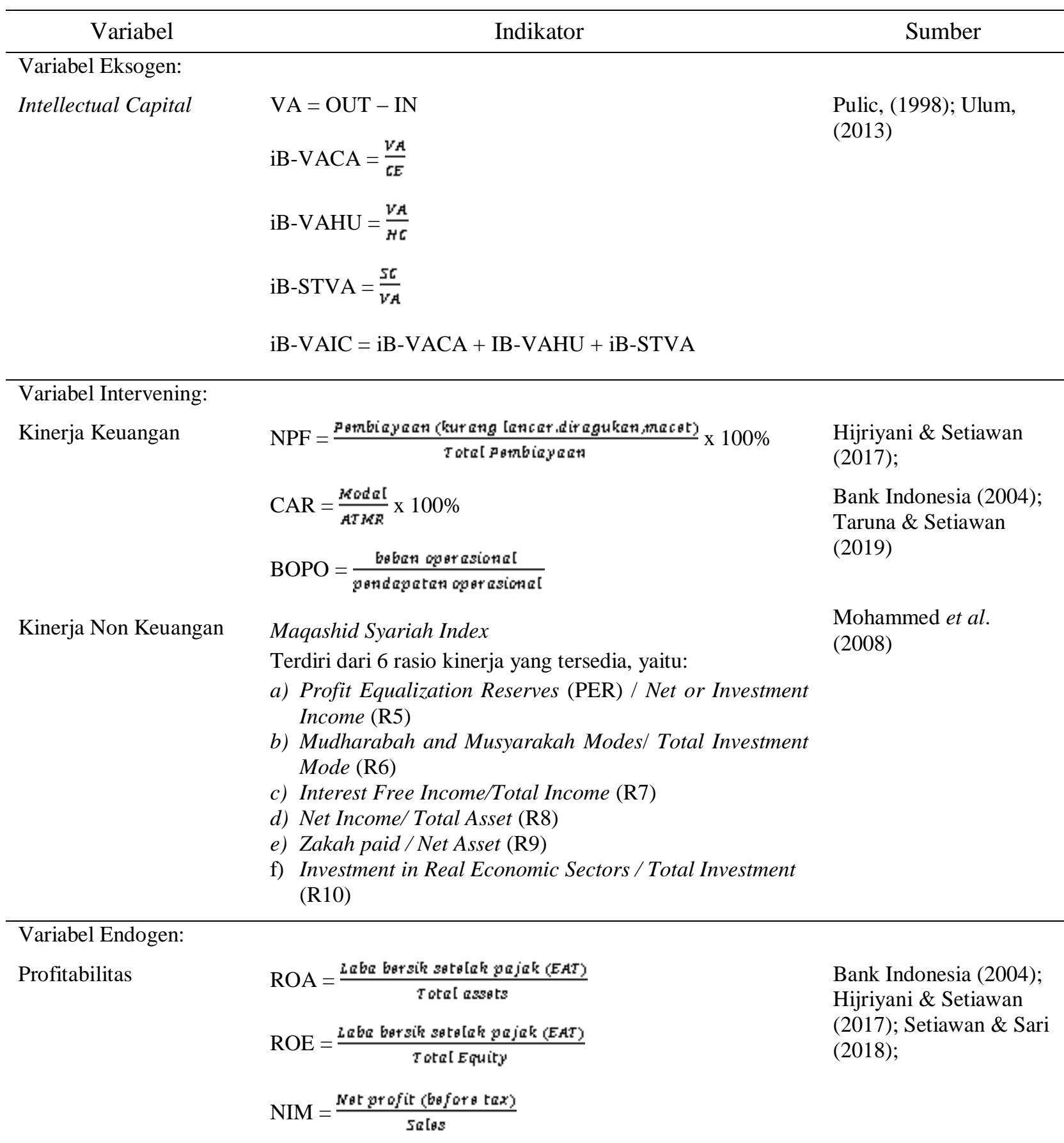

Sumber: Diolah penulis, 2019.

Selanjutnya untuk memastikan bahwa setiap konsep dari masing variabel laten berbeda dengan variabel lainnya dapat dinilai menggunakan discriminant validity. Model mempunyai discriminant validity yang baik jika setiap nilai loading dari setiap indikator dari sebuah variabel laten memiliki nilai loading paling besar dibandingkan dengan nilai loading lain terhadap variabel laten lainnya. Berdasarkan Tabel 4, yang menunjukkan hasil pengujian discriminant validity, diperoleh semua nilai loading factor untuk setiap indikator dari masing-masing variabel laten memiliki nilai yang lebih besar jika dibandingkan dengan variabel laten lainnya. 
Tabel 2. Hasil Statistik Deskriptif

\begin{tabular}{llrrrrrr}
\hline \multicolumn{1}{c}{ Variabel } & \multicolumn{1}{c}{ Indikator } & $\mathrm{N}$ & Mean & Median & Min & Maks & $\begin{array}{c}\text { Std. } \\
\text { Deviasi }\end{array}$ \\
\hline Intellectual Capital & IB-VACA & 140 & 0.206 & 0.155 & 0.03 & 0.921 & 0.159 \\
& IB-VAHU & 140 & 1.413 & 1.393 & 0.747 & 2.843 & 0.269 \\
& IB-STVA & 140 & 0.268 & 0.282 & -0.339 & 0.648 & 0.138 \\
\hline Kinerja Keuangan & FDR & 140 & 0.905 & 0.916 & 0.719 & 1.056 & 0.075 \\
& NPF & 140 & 0.038 & 0.034 & 0.013 & 0.072 & 0.014 \\
& CAR & 140 & 0.201 & 0.163 & 0.107 & 0.643 & 0.097 \\
\hline Kinerja Non Keuangan & Tujuan Penciptaan & 140 & 1.451 & 1.461 & 0.827 & 1.879 & 0.203 \\
& Keadilan & & & & & & \\
& Tujuan Pencapaian & 140 & 0.898 & 0.924 & 0.506 & 1.122 & 0.091 \\
& Kepentingan Publik & & & & & & \\
\hline Profitabilitas & ROA & 140 & 0.011 & 0.01 & -0.012 & 0.049 & 0.009 \\
& ROE & 140 & 0.089 & 0.067 & -0.137 & 0.588 & 0.109 \\
& NIM & 140 & 0.072 & 0.076 & 0.024 & 0.161 & 0.031 \\
\hline
\end{tabular}

Sumber: Data sekunder diolah, 2019.

Tabel 3. Hasil Outer Loading dan AVE Setelah Perbaikan

\begin{tabular}{llrr}
\hline \multicolumn{1}{c}{ Variabel } & \multicolumn{1}{c}{ Item } & Outer Loading & AVE \\
\hline Intellectual Capital & VAHU & 0.983 & \\
& STVA & 0.984 & \\
Kinerja Keuangan & BOPO & 1 & 1 \\
Kinerja Non Keuangan & Tujuan Penciptaan Keadilan & 1 & 1 \\
Profitabilitas & ROA & 0.928 & 0.764 \\
& ROE & 0.938 & \\
& NIM & 0.743 & \\
\hline
\end{tabular}

Sumber: Data primer diolah, 2019.

Tabel 4. Hasil Discriminant Validity (Cross Loading)

\begin{tabular}{lrrrr}
\hline & $\begin{array}{c}\text { Kinerja } \\
\text { Keuangan }\end{array}$ & $\begin{array}{c}\text { Kinerja Non } \\
\text { Keuangan }\end{array}$ & Profitabilitas & \multicolumn{1}{c}{ IB-VAIC } \\
\hline BOPO & 1 & 0.038 & -0.763 & -0.768 \\
NIM & -0.386 & -0.645 & 0.743 & -0.001 \\
ROA & -0.83 & -0.156 & 0.928 & 0.758 \\
ROE & -0.722 & -0.314 & 0.938 & 0.518 \\
IB-STVA & -0.766 & 0.328 & 0.51 & 0.984 \\
Tujuan Penciptaan Keadilan & 0.038 & 1 & -0.389 & 0.293 \\
IB-VAHU & -0.744 & 0.248 & 0.538 & 0.983 \\
\hline
\end{tabular}

Sumber: Data sekunder diolah, 2019. 
Berdasarkan Tabel 4 dapat dilihat nilai setiap korelasi variabel dengan indikatornya lebih tinggi dibanding dengan nilai korelasi variabel dengan indikator yang lain. Hasil ini menunjukkan komponen dari seluruh variabel laten dapat memprediksi indikator pada blok mereka yaitu lebih baik dibandingkan dengan indikator blok lainnya (Ghozali, 2008).

Pada variabel kinerja keuangan, nilai korelasi indikator BOPO lebih besar dibanding indikator lainnya. Pada variabel kinerja non keuangan, nilai korelasi tujuan penciptaan keadilan lebih besar dibanding indikator lainnya. Pada variabel profitabilitas, nilai korelasi NIM, ROA, dan ROA lebih besar dibanding indikator lainnya. Pada variabel Intellectual Capital, nilai korelasi IBSTVA dan IB-VAHU besar dibanding indikator lainnya.

Di samping uji validitas konstruk, juga dilakukan pengujian reliabilitas konstruk yang diukur dengan composite reliability dari blok indikator yang mengukur konstruk. Konstruk dapat dinyatakan reliabel jika nilai composite reliability adalah di atas 0,70 (Ghozali, 2008). Berdasarkan Tabel 5 bisa diidentifikasi setiap item memiliki nilai composite reliability yang berbeda-beda, namun seluruhnya masih di atas 0,70 - bahkan mendekati angka 1. Hasil ini menunjukkan bahwa variabel tersebut sangat reliable (Ghozali, 2008).

Tabel 5. Hasil Uji Composite Reliability

\begin{tabular}{lr}
\hline & Composite Reliability \\
\hline KK & 1 \\
KNK & 1 \\
Profitabilitas & 0.906 \\
VAIC & 0.983 \\
\hline
\end{tabular}

Sumber: Data primer diolah, 2019.

Selanjutnya dilakukan pengujian model struktural (inner model). Penilaian inner model yaitu untuk melihat hubungan antar variabel dengan melihat atas hasil koefisien parameter path dan tingkat signifikansinya (Ghozali, 2008). Uji ini dapat menunjukkan hubungan antara konstruk dengan nilai signifikansinya, serta juga nilai $R$-square. Sedangkan $R$-Square dapat melihat pengaruh dari variabel independen terhadap variabel dependen (Ghozali, 2008). Semakin besar angka $R$-square dapat menunjukkan semakin besar variabel eksogen tersebut berarti lebih dapat menjelaskan variabel endogen, sehingga semakin baik persamaan struktural (Ghozali, 2008). Tabel 6 adalah rangkuman perhitungan inner model dari data yang didapatkan serta digunakan oleh peneliti dengan menggunakan analisis Partial Least Square.

\section{Tabel 6. Hasil R-Square}

\begin{tabular}{lc}
\hline \multicolumn{1}{c}{ Variabel } & R-Square \\
\hline Kinerja Keuangan & 0.59 \\
Kinerja Non Keuangan & 0.086 \\
Profitabilitas & 0.724 \\
\hline
\end{tabular}

Sumber: Data sekunder diolah, 2019.

Hasil $R$-square pada Kinerja Keuangan menunjukkan nilai 0,59 yang artinya Kinerja Keuangan dapat dijelaskan oleh Intellectual Capital sebesar 59\% dan sisanya $31 \%$ dijelaskan oleh variabel lain. Hasil $R$-square pada variabel Kinerja Non Keuangan menunjukkan nilai 0,086 yang artinya Kinerja Keuangan dijelaskan oleh Intellectual Capital sebesar $8,6 \%$ dan sisanya $91.4 \%$ dijelaskan oleh variabel lain. Hasil $R$-square pada variabel Profitabilitas menunjukkan nilai 0,724 yang artinya Profitabilitas dapat dijelaskan oleh Intellectual Capital, Kinerja Keuangan dan Kinerja Non Keuangan sebesar $72,4 \%$, sementara sisanya $27,6 \%$ dijelaskan oleh variabel lain.

Dari hasil $R$-square dapat disimpulkan bahwa model penelitian ini, yaitu Intellectual Capital, Kinerja Keuangan, dan Kinerja Non Keuangan dalam mempengaruhi Profitabilitas menjadi model terbaik yang diperoleh yang 
memperlihatkan pola hubungan dengan nilai tertinggi. Nilai koefisiennya mencapai $72,4 \%$ yang menunjukkan adanya pola hubungan yang sangat kuat karena nilai itu mendekati angka 1 atau pengaruh yang sempurna.

Tabel 7. Hasil Koefisien Jalur dan Pengaruh Tidak Langsung

\begin{tabular}{lrrrrr}
\hline & $\begin{array}{c}\text { Sampel Asli } \\
(\mathrm{O})\end{array}$ & $\begin{array}{c}\text { Sample } \\
\text { Mean }(\mathrm{M})\end{array}$ & $\begin{array}{c}\text { Standar } \\
\text { Deviasi } \\
(\text { STDEV })\end{array}$ & $\begin{array}{c}\text { T Statistik } \\
(\mid \text { O/STDEV })\end{array}$ & P Values \\
\hline VAIC -> KK & -0.768 & -0.76 & 0.063 & 12.247 & $0.000^{*}$ \\
VAIC -> KNK & 0.293 & 0.283 & 0.108 & 2.721 & $0.007^{*}$ \\
VAIC -> Profitabilitas & 0.207 & 0.211 & 0.113 & 1.83 & 0.068 \\
KK -> Profitabilitas & -0.588 & -0.586 & 0.095 & 6.168 & $0.000^{*}$ \\
KNK -> Profitabilitas & -0.427 & -0.431 & 0.051 & 8.397 & $0.000^{*}$ \\
VAIC -> KK -> Profitabilitas & 0.452 & 0.456 & 0.089 & 5.093 & $0.000^{*}$ \\
VAIC -> KNK -> Profitabilitas & -0.125 & -0.128 & 0.049 & 2.551 & $0.011^{* *}$ \\
\hline
\end{tabular}

*Signifikan pada level 1\%; **Signifikan pada level 5\%

Sumber: Data primer diolah, 2019.

Tabel 7 menunjukkan hasil-hasil yang mengkonfirmasi hipotesis-hipotesis yang diajukan dalam penelitian ini. Hasil pertama memperoleh bahwa parameter hubungan IBVAIC terhadap Kinerja Keuangan (KK) adalah sebesar $-0,768$ dan nilai p-value sebesar 0,000. Pada tingkat signifikansi 1\%, hubungan antara IB-VAIC terhadap Kinerja Keuangan (KK) dinyatakan signifikan karena nilai p-value $<0,05$. Karenanya dapat dinyatakan IB-VAIC berpengaruh negatif secara signifikan terhadap Kinerja Keuangan (KK), sehingga hipotesis pertama yang diajukan dalam penelitian ini tidak didukung.

Hasil kedua yang diperoleh dari Tabel 7 menunjukkan bahwa parameter hubungan IBVAIC terhadap Kinerja Non Keuangan (KNK) adalah sebesar 0,293 dan nilai p-value sebesar 0,007. Pada tingkat signifikansi 1\%, hubungan antara IB-VAIC terhadap Kinerja Keuangan (KK) terbukti signifikan karena nilai $\mathrm{p}$-value $<0,05$, sehingga dapat diartikan bahwa IB-VAIC berpengaruh positif secara signifikan terhadap Kinerja Non Keuangan (KNK). Dengan demikian, hipotesis kedua dalam penelitian ini didukung.
Hasil ketiga berdasarkan Tabel 7 adalah bahwa parameter hubungan IB-VAIC atas Profitabilitas sebesar 0,207 dan nilai p-value sebesar 0,068. Pada tingkat signifikansi $1 \%$ atau 5\%, hubungan antara IB-VAIC terhadap Profitabilitas dinyatakan tidak signifikan karena nilai p-value $>0.05$. Karenanya dapat diartikan bahwa IB-VAIC berpengaruh positif tetapi tidak signifikan terhadap Kinerja Profitabilitas, sehingga hipotesis ketiga dari penelitian ini tidak didukung.

Hasil keempat yang diperoleh dari Tabel 7 bahwa parameter hubungan Kinerja Keuangan (KK) terhadap Profitabilitas adalah sebesar -0,588 dan nilai p-values sebesar 0,000. Pada level signifikansi 5\%, hubungan antara Kinerja Keuangan (KK) terhadap Profitabilitas signifikan karena nilai p-value < 0.01 , sehingga dapat diartikan bahwa Kinerja Keuangan (KK) berpengaruh negatif secara signifikan terhadap Profitabilitas. Dengan demikian, hipotesis keempat dari penelitian ini tidak didukung.

Hasil kelima berdasarkan Tabel 7 menunjukkan bahwa parameter hubungan Kinerja Non Keuangan (KNK) terhadap Profitabilitas adalah sebesar $-0,427$ dan nilai 
p-value sebesar 0,000. Pada level signifikansi $1 \%$, hubungan antara Kinerja Non Keuangan (KNK) terhadap Profitabilitas dinyatakan signifikan karena nilai p-value $<0,05$, sehingga dapat diartikan bahwa Kinerja Non Keuangan (KNK) berpengaruh negatif secara signifikan terhadap Profitabilitas. Dengan demikian, hipotesis kelima dalam penelitian ini tidaklah didukung.

Hasil keenam yang diperoleh berdasarkan Tabel 7 adalah bahwa parameter hubungan IB-VAIC terhadap Profitabilitas melalui Kinerja Keuangan sebesar 0,452 dan nilai p-value sebesar 0,000. Pada tingkat signifikansi 5\%, hubungan antara IB-VAIC terhadap Profitabilitas melalui Kinerja Bank Syariah dinyatakan signifikan karena nilai pvalue $<0,05$. Dengan demikian, dinyatakan bahwa IB-VAIC berpengaruh positif secara signifikan terhadap Profitabilitas melalui Kinerja Keuangan; atau, bahwa hipotesis keenam dari penelitian ini dapat didukung.

Hasil terakhir yang diperoleh berdasarkan Tabel 7 bahwa parameter hubungan IBVAIC terhadap Profitabilitas melalui Kinerja Non Keuangan sebesar -0,125 dan nilai pvalue sebesar 0,011. Pada tingkat signifikansi $5 \%$, hubungan antara IB-VAIC terhadap Profitabilitas melalui Kinerja Bank Syariah dinyatakan signifikan karena nilai p-value < 0.05 . Karenanya bisa diartikan bahwa IBVAIC memiliki pengaruh negatif secara signifikan terhadap Profitabilitas melalui Kinerja Non Keuangan, sehingga hipotesis ketujuh yang diajukan dalam penelitian ini tidak didukung.

\section{Pembahasan}

\section{Pengaruh Intellectual Capital terhadap Kinerja Keuangan}

Hasil penelitian menyatakan bahwa IBVAIC berpengaruh secara negatif dan signifikan terhadap kinerja keuangan. Hasil penelitian ini menunjukkan hubungan yang negatif, dalam arti bahwa semakin tinggi nilai intellectual capital maka semakin rendah nilai BOPO. Ketika intellectual capital meningkat, maka biaya operasional yang dikeluarkan oleh bank syariah menjadi berkurang, sehingga lebih efisien. Hal ini berarti jika nilai intellectual capital meningkat, maka biaya operasional dapat diminimalisir. Hasil ini sejalan dengan temuan Chen et al. (2005) bahwa intellectual capital merupakan elemen sumber daya yang memiliki peran di dalam meningkatkan keunggulan bersaing melalui peningkatan kinerja keuangan perusahaan. Hasil penelitian ini juga mendukung beberapa hasil penelitan terdahulu lainnya seperti milik Lestari et al. (2016) serta Wijayani, (2017).

\section{Pengaruh Intellectual Capital terhadap Kinerja Non Keuangan}

Hasil penelitian yang kedua diperoleh bahwa IB-VAIC terbukti memiliki pengaruh yang positif dan signifikan terhadap kinerja non keuangan. Hasil ini semakin mendukung bahwa Intellectual Capital dapat dianggap sebagai bagian dari aset perusahaan. Namun demikian, seperti menurut Suwarjono \& Kadir (2003), intellectual capital hanya dapat dianggap sebagai aset dan belum dapat diperlakukan sebagai aset seperti aset-aset lainnya yang dapat diukur dan dilaporkan dalam laporan keuangan perusahan. Hal ini karena intellectual capital dinilai relatif sulit untuk diukur secara kuantitatif.

\section{Pengaruh Intellectual Capital terhadap Profitabilitas}

Pada pola hubungan ini, hasil penelitian menunjukkan bahwa IB-VAIC berpengaruh positif dan tidak signifikan atas profitabilitas; atau, bahwa intellectual capital berpengaruh secara positif namun tidak signifikan terhadap profitabilitas. Pada dasarnya, nilai intellectual capital yang semakin tinggi akan meningkatkan nilai profitabilitas. Namun lebih jauh, 
variabel ini tidak mempunyai pengaruh yang berarti terhadap profitabilitas pada Bank Umum Syariah di Indonesia.

\section{Pengaruh Kinerja Keuangan terhadap Profitabilitas}

Hasil penelitian berikutnya menyatakn bahwa kinerja keuangan berpengaruh secara negatif dan signifikan terhadap profitabilitas. Hasil ini dinilai diperoleh karena kinerja keuangan diproksikan oleh BOPO, yaitu rasio yang digunakan untuk mengukur perbandingan biaya operasional dengan pendapatan operasional. Ketika terjadi peningkatan terhadap BOPO, maka profitabilitas akan menurun. Sebaliknya, bila terjadi penuruana terhadap BOPO maka profitabilitas akan meningkat. Hasil penelitian ini didukung oleh penelitian terdahulu yang dilakukan oleh Margaretha \& Marsheily (2013) serta Putri \& Dewi (2017) yang menyatakan bahwa adanya pengaruh negatif dan signifikan antara BOPO terhadap profitabilitas.

\section{Pengaruh Kinerja Non Keuangan terhadap Profitabilitas}

Pada pola hubungan ini, hasil penelitian menemukan bahwa kinerja non keuangan berpengaruh negatif dan signifikan terhadap profitabilitas. Hasil ini dinilai terjadi karena profitabilitas masih sangat dipengaruhi oleh faktor finansial. Dengan kata lain, faktor finansial masih menjadi faktor utama yang dilihat investor sebelum melakukan investasi. Padahal dari adanya investasi ini, bank syariah mendapat profit. Indikator kinerja non keuangan maqashid syariah hanya dijadikan sebagai informasi tambahan yang mendukung informasi keuangannya. Karenanya ketika kinerja non keuangan mengalami penurunan, maka profitabilitas naik, akibat pertimbangan investor yang masih hanya memperhatikan aspek kinerja keuangan.

\section{Pengaruh Intellectual Capital terhadap Profitabilitas melalui Kinerja Keuangan}

Hasil analisis atas jalur mediasi yang pertama menunjukkan terdapat pengaruh tidak langsung secara positif dan signifikan oleh intellectual capital terhadap profitabilitas melalui kinerja keuangan pada Bank Umum Syariah di Indonesia. Intellectual capital yang dikelola dengan baik oleh perusahaan dapat menciptakan nilai tambah (value added) bagi perusahaan itu sendiri. Atas dasar nilai tambah tersebut maka para penyandang dana akan memberikan nilai tambah juga kepada perusahaan dengan cara berinvestasi lebih tinggi. Nilai tambah selanjutnya ini akan meningkatkan kinerja keuangan perusahaan, dan pada akhirnya membuat keuntungan yang diperoleh perusahaan juga meningkat. Hal ini selaras dengan penelitian yang dilakukan oleh Chen et al. (2005), Lestari et al. (2016), dan Wijayani (2017) yang menemukaan bahwa terdapat pengaruh yang positif dan signifikan dari intellectual capital terhadap kinerja keuangan. Dengan demikian, semakin baik nilai intellectual capital maka kinerja keuangan pada perbankan syariah akan semakin baik, yang berdampak pula pada profitabilitas dari bank yang bersangkutan.

\section{Pengaruh Intellectual Capital terhadap Profitabilitas melalui Kinerja Non Keuangan}

Hasil analisis pada pola mediasi yang kedua menunjukkan IB-VAIC berpengaruh secara negatif dan signifikan terhadap Profitabilitas melalui Kinerja Non Keuangan. Hal ini berarti intellectual capital memiliki arah hubungan yang bersifat negatif secara signifikan terhadap profitabilitas melalui kinerja non keuangan pada Bank Umum Syariah di Indonesia. Ditinjau dari segi total biaya infrastruktur dan sistem kegiatan operasi yang dikeluarkan, perusahaan dinilai tidak mampu memberi nilai tambah atau 
value added terhadap pemenuhan maqashid syariah. Hal ini mungkin terjadi karena perusahaan lebih berfokus untuk membangun kondisi internal perusahaan secara efektif dan efisien terlebih dulu. Dengan terciptanya kondisi internal yang baik diharapkan dapat menciptakan value added yang tinggi pula dimasa mendatang. Efek dari value added yang tinggi ini adalah perusahaan dapat menyisihkan kelebihan incomenya untuk kemaslahatan umat secara luas, khususnya di Indonesia.

Implikasi dari pengelolaan structural capital menunjukkan tidak adanya pengaruh pada penciptaan kinerja maqashid syariah. Maksudnya dari setiap kegiatan penerapan dan pengelolaan sistem keorganisasian, kekayaan intelektual, teknologi atau sistem perbankan dan transparansi yang dilakukan perbankan syariah hanyalah berdasarkan tindakan legitimasi perbankan yang berusaha menciptakan nilai perusahaan semata. Ditinjau dari teori RBT, hal ini juga menandakan perbankan syariah dalam hal pengelolaan structural capital adalah sama saja dengan perbankan konvensional yang berorientasi menarik nasabah demi mendapat profit dan memiliki nilai yang tinggi dimata stakeholder.

Lebih lanjut pengelolaan structural capital untuk penciptaan maqashid syariah dirasa belum tepat sasaran karena perusahaan melakukan pengelolaan structural capital berdasarkan tindakan isomorfisma mimetic atau meniru-niru. Kecenderungan tindakan isomofisma mimetic ini mencerminkan sikap organisasi pada operasional kerja hanya sebatas kegiatan formal, bukan berorientasi pada substansi (Sofyani \& Akbar, 2013). Maksud dari penjelasan ini yaitu setiap kegiatan penerapan sistem keorganisasian, kekayaan intelektual, teknologi atau sistem perbankan dan transparansi hanya dilakukan sebatas formalitas atas regulasi perbankan yang ada atau budaya perusahaan sejenis, dan bukan dilakukan secara sukarela demi kemaslahatan umat.

\section{SIMPULAN}

Berdasarkan pemaparan hasil penelitian pada pembahasan sebelumnya, bisa disimpulkan beberapa hal. Simpulan pertama bahwa intellectual capital dinilai tidak berpengaruh terhadap kinerja keuangan maupun terhadap profitabilitas, tetapi berpengaruh positif dan signifikan terhadap kinerja non keuangan maqashid syariah pada Bank Umum Syariah. Simpulan kedua bahwa baik kinerja keuangan maupun kinerja non keuangan tidak berpengaruh terhadap profitabilitas. Simpulan ketiga bahwa intellectual capital berpengaruh secara positif dan signifikan terhadap profitabilitas melalui jalur mediasi kinerja keuangan; namun tidak berpengaruh atas profitabilitas melalui jalur mediasi kinerja non keuangan, pada Bank Umum Syariah.

Bagi manajer perbankan syariah direkomendasikan untuk mengelola intellectual capital dengan baik. Untuk dapat mencapai kinerja keuangan unggul, perusahaan diharapkan dapat mengembangkan dan mengelola intellectual capital dalam segala bentuk dan dimensinya. Human capital yang produktif serta bermanfaat bagi perusahaan akan menjadi elemen potensial dalam pelonjakan produktivitas. Jika perusahaan mampu menggunakan knowledge yang dimiliki oleh karyawannya, maka human capital akan melonjak. Ketika sumber daya manusianya mampu dalam mengelola perusahaan, maka profitabilitas meningkat. Human capital ini dapat ditingkatkan dengan mengadakan pelatihan, pendidikan, seminar dan hal lainnya yang dapat menambah keahlian (skill) ataupun keterampilan (knowhow) karyawan. 


\section{REFERENSI}

Al-Ghazali. 1985. Ihya'ulum al-Din, Alih bahasa: Prof. Ismail Yakub. Jilid 7, Cetakan 3. Jakarta: CV. Faizan.

Almilia, L.S. \& Kristijadi, K. 2003. Analisis Rasio Keuangan untuk Memprediksi Kondisi Financial Distress Perusahaan Manufaktur yang Terdaftar di Bursa Efek Jakarta. Jurnal Akuntansi dan Auditing Indonesia. 7(2): 183-210.

Aminah. 2017. Analisis Pengaruh Intellectual Capital dan Islamicity Performance Index terhadap Return on Assets pada BMT Mardlotillah Sumedang Periode 2014-2016. Tugas Akhir. Bandung: Politeknik Negeri Bandung.

Asy-Syatibi. t.t . al-Muwafaqat fi Ushul alSyariah. Jilid 1. Kairo: Mustafa Muhammad.

Bank Indonesia. 2004. Surat Edaran Bank Indonesia Nomor 6/23/DPNP Perihal Sistem Penilaian Tingkat Kesehatan Bank. www.bi.go.id.

Bontis, N. 1998. Intellectual Capital: An Exploratory Study that develops measures and Models. Management Decision. 36(2): 63-76.

Brooking. 1996. Intellectual Capital: Core Asset for Third Millennium Enterprise. London: International Thomson Business Press.

Chen, M.C., Cheng, S.J. \& Hwang, Y. 2005. An Empirical Investigation of the Relationship between Intellectual Capital and firms' Market Value and Financial Performance. Journal of Intellectual Capital. 6(2): 159-176.

Ghozali, I. 2008. Structural Equation Modeling: Metode Alternatif dengan Partial Least Square (PLS). Semarang: Badan Penerbit Universitas Diponegoro.

Hanafi, M. 2003. Manajemen Keuangan. Yogyakarta: BPFE.

Hanafi, M.M. \& Halim, A. 2009. Analisis Laporan Keuangan. Edisi 4. Yogyakarta: UPP STIM YKPN.

Harmono. 2014. Manajemen Keuangan Berbasis Balanced Sorecard
Pendekatan Teori, Kasus dan Riset Bisnis. Jakarta: Bumi Aksara.

Harrison, S. \& Sulivan, P.H. 2000. Profiting from Intellectual Capital: Learning from Leading Companies. Journal of Intellectual Capital. 1(1): 33-46.

Hijriyani, N.Z. \& Setiawan. 2017. Analisis Profitabilitas Perbankan Syariah di Indonesia sebagai Dampak dari Efisiensi Operasional. Jurnal Kajian Akuntansi. 1(2): 194-209.

Lestari, S.D., Paramu, H. \& Sukarno, H. 2016. Pengaruh Intellectual Capital terhadap Kinerja Keuangan Perbankan Syari'ah di Indonesia. Ekuitas: Jurnal Ekonomi dan Keuangan. 20(3): 346366.

Margaretha, F. \& Marsheily, P.Z. 2013. Faktor-Faktor yang Mempengaruhi Kinerja Keuangan Perbankan Indonesia. Jurnal Bisnis dan Akuntansi. 15(2): 133-141.

Meutuah, R. \& Takidah, E. 2014. Analisis Pengaruh Efisiensi Sumber Daya Bank Umum Syariah terhadap Kinerja Perusahaan. Tazkia Islamic Finance and Business Review. 5(2): 147-166.

Mohammed, M.O., Razak, D.A. \& Taib, F.M.. 2008. The Performance Measures of Islamic Banking Based on the Maqasid Framework. IIUM International Accounting Conference (INTAC IV). Putra Jaya Marroitt.

Nasih, M. 2010. Intellectual Capital dan Kinerja Perusahaan Perbankan di Indonesia. Majalah Ekonomi. 20 (2): 181-190.

Organization for Economic Co-operation and Development (OECD). 1999. International Symposium on Measuring and Reporting Intellectual Capital: Experience, Issues and Prospects. Amsterdam, 9-11 Juni 1999.

Prambodo, B.Y.W. \& Amanah, L. 2016. Analisis Pengaruh Intellectual Capital terhadap Likuiditas Perusahaan Perbankan Syariah. Jurnal Ilmu dan Riset Manajemen. 5(11): 1-15. 
Pulic, A. 1998. Measuring the Performance of Intellectual Potential in Knowledge Economy. The 2nd McMaster World Congress on Measuring and Managing Intellectual Capital. The Austrian Team for Intellectual Potential.

Putri, R.N.O.S. \& Dewi, S.K.S. 2017. Pengaruh LDR, CAR, NPL, BOPO terhadap Profitabilitas Lembaga Perkreditan Desa di Kota Denpasar. EJurnal Manajemen Unud. 6(10): 5607-5630

Ramadhan, M.I.B, Abdurahim, A. \& Sofyani, H. 2018. Modal Intelektual dan Kinerja Maqashid Syariah Perbankan Syariah di Indonesia. Jurnal Akuntansi dan Keuangan Islam. 6(1): 5-18

Roos J., Roos, G., Dragonetti, N.C. \& Edvinsson, L. 1997. Intellectual Capital: Navigating in the New Business Landscape. Houndsmills: Macmillan Business.

Setiawan, S. 2018. Determinan Penentu Pertumbuhan Dana Pihak Ketiga Perbankan Syariah di Indonesia. Jurnal MAPS (Manajemen dan Perbankan Syariah). 1(2): 1-9.

Setiawan, S. \& Sari, R.M., 2018. Rentabilitas Bank Umum Syariah Sesudah Spin-Off Berdasarkan Tipe Pemisahannya di Indonesia. Amwaluna: Jurnal Ekonomi dan Keuangan Syariah. 2(1): 69-87.

Setyowati, D.H., Sartika, A. \& Setiawan, S. 2019. Faktor-Faktor yang Mempengaruhi Pangsa Pasar Industri Keuangan Syariah Non-Bank. Jurnal Iqtisaduna. 5(2): 169-186.

Sofyani, H. \& Akbar, R. 2013 Hubungan Faktor Internal Institusi dan Implementasi Sistem Akuntabilitas Kinerja Instansi Pemerintah (SAKIP) di Pemerintah Daerah. Jurnal Akuntansi dan Keuangan Indonesia. 10 (2): 184-205
Solikhah, B. 2010. Pengaruh Intellectual Capital terhadap Kinerja Keuangan Perusahaan, Pertumbuhan dan Nilai Pasar pada Perusahaan yang Tercatat di Bursa Efek Indonesia. Tesis. Semarang: Universitas Diponegoro.

Stewart, T.A. 1991. Brain Power: How Intellectual Capital is Becoming America's Most Valuable Asset. Fortune. 3(June): 44-60.

Sugiyono. 2010. Metode Penelitian Kuantitatif, Kualitatif, dan R\&D. Bandung: CV Alfabeta.

Suwarjono, T. \& Kadir. 2003. Intellectual Capital: Perlakuan, Pengukuran, dan Pelaporan (Sebuah Library Research). Jurnal Ekonomi dan Bisnis Indonesia. 15(2): 247-256.

Taruna, R.D. \& Setiawan. 2019. Pengaruh Kinerja Keuangan terhadap Pertumbuhan Laba Bank Umum di Indonesia. Jurnal Accounting Information System. 2(1): 1-9

Ulum, I. 2008. Pengaruh Intellectual Capital terhadap Kinerja Keuangan Perusahaan Perbankan di Indonesia. Thesis. Semarang: Universitas Diponegoro.

Ulum, I. 2013. Model Pengukuran Kinerja Intellectual Capital dengan IB-VAIC di Perbankan Syariah. INFERENSI. 7(1): 185-206.

Wernerfelt, B. 1984. A Resource Based View of the Firm. Strategic Management Journal. 64(3): 462-479.

Wijaya, M.H. \& Amanah, L. 2017. Pengaruh Intellectual Capital terhadap Kinerja Perusahaan Otomotif di Bursa Efek Indonesia. Jurnal Ilmu dan Riset Akuntansi. 6(1).

Wijayani, D.R. 2017. Pengaruh Intellectual Capital terhadap Kinerja Keuangan Perusahaan Publik di Indonesia. Jurnal Riset Akuntansi dan Bisnis Airlangga. 2(1): 97-116. 